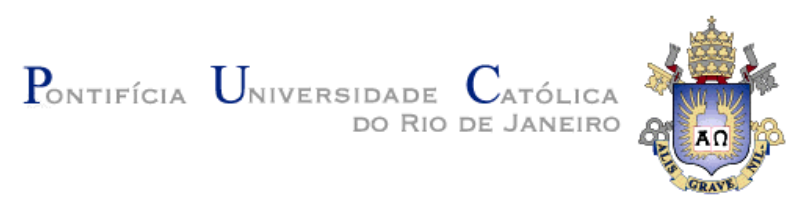

Lívia Couto Ruback Rodrigues

\title{
LDC Mediator: A Mediator for Linked Data Cubes
}

\section{Dissertação de Mestrado}

Dissertation presented to the Programa de PósGraduação em Informática of the Departamento de Informática da PUC-Rio as partial fulfillment of the requirements for the degree of Mestre.

Advisor: Prof. Marco Antonio Casanova

Rio de Janeiro

September 2013 


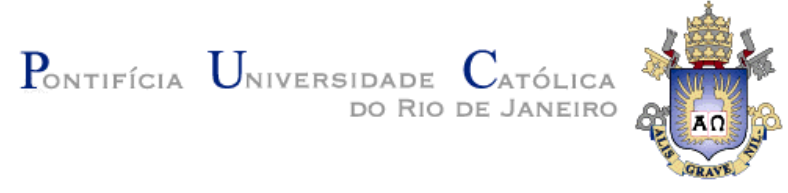

\section{Lívia Couto Ruback Rodrigues}

\section{LDC Mediator: A Mediator for Linked Data Cubes}

Dissertation presented to the Programa de Pós-Graduação em Informática of the Departamento de Informática do Centro Técnico Científico da PUC-Rio, as partial fulfillment of the requirements for the degree of Mestre.

Prof. Marco Antonio Casanova

Advisor

Departamento de Informática - PUC-Rio

Prof. Antonio Luz Furtado

Departamento de Informática - PUC-Rio

Prof. Luiz André Portes Paes Leme

Departamento de Informática - UFF

Profa. Giseli Rabello Lopes

Departamento de Informática - PUC-Rio

Prof. José Eugenio Leal

Coordenador Setorial do Centro

Técnico Científico - PUC-Rio

Rio de Janeiro, September 12th, 2013 
All rights reserved.

\section{Lívia Couto Ruback Rodrigues}

Graduated in Computer Science from Universidade Federal de Juiz de Fora (UFJF), Minas Gerais - Brazil in 2009. She joined the Master in Informatics at Pontifical Catholic University of Rio de Janeiro (PUC-Rio) in 2011. Her main research interests cover Web Semantic and Linked Data.

Bibliographic data

Couto Ruback Rodrigues, Lívia

LDC Mediator: a Mediator for Linked Data Cubes / Lívia Couto Ruback Rodrigues; advisor: Marco Antonio Casanova. - 2013.

69 f. : il. (color) ; $30 \mathrm{~cm}$

Dissertação (Mestrado) - Pontifícia Universidade Católica do Rio de Janeiro, Departamento de Informática, 2013.

Inclui bibliografia

1. Informática - Teses. 2. Dados Estatísticos. 3. Dados ligados. 4. Arquitetura de mediação. 5. Triplificação. 6. RDF. 7. Cubo de Dados OLAP. 8. REST. I. Casanova, Marco Antonio. II. Pontifícia Universidade Católica do Rio de Janeiro. Departamento de Informática. III. Título. 


\section{Acknowledgments}

I would like to say a special thank you to Marco Antonio Casanova, the best advisor I could ever ask for. His wisdom, knowledge, refined sense of humor and kindness were essential to motivate me to keep going and finish this work.

To Profa. Simone for her classes and for the best brownies recipe.

To PUC-Rio for giving me the opportunity to make such important lifelong friends.

To my family and friends. In particular to my parents Rubens and Izabel for their support raising me. To my sisters Flávia and Bianca for all the wonderful memories.

To my boyfriend and partner Adriano, for still being there no matter what. Even taking up dance classes to dance with me.

To CAPES for funding my research. 


\section{Abstract}

Ruback, Lívia; Casanova, Marco Antonio (Advisor). LDC Mediator: A Mediator for Linked Data Cubes. Rio de Janeiro, 2013. 69p. MSc. Dissertation - Departamento de Informática, Pontifícia Universidade Católica do Rio de Janeiro.

A statistical data set comprises a collection of observations made at some points across a logical space and is often organized as what is called a data cube. The proper definition of the data cubes, especially of their dimensions, helps to process the observations and, more importantly, helps to combine observations from different data cubes. In this context, the Linked Data Principles can be profitably applied to the definition of data cubes, in the sense that the principles offer a strategy to provide the missing semantics of the dimensions, including their values. This work introduces a mediation architecture to help consume linked data cubes, exposed as RDF triples, but stored in relational databases. The data cubes are described in a catalogue using standardized vocabularies and are accessed by HTTP methods using REST principles. Therefore, this work aims at taking advantage of both Linked Data and REST principles in order to describe and consume linked data cubes in a simple but efficient way.

\section{Keywords}

Statistical Data, Linked Data, Mediation Architecture, Triplification, RDF, OLAP Data Cube, REST. 


\section{Resumo}

Ruback, Lívia; Casanova, Marco Antonio. Mediador LDC: Um mediador de Cubos de Dados Interligados. Rio de Janeiro, 2013. 69p. Dissertação de Mestrado - Departamento de Informática, Pontifícia Universidade Católica do Rio de Janeiro.

Um banco de dados estatístico consiste de um conjunto de observações feitas em pontos de um espaço lógico, e, muitas vezes, são organizados como cubos de dados. A definição adequada de cubos de dados, em especial de suas dimensões, ajuda a processar as suas observações e, mais importante, ajuda a combinar observações de cubos de dados diferentes. Neste contexto, os princípios de dados interligados podem ser proveitosamente aplicados à definição de cubos de dados, oferecendo uma estratégia para fornecer a semântica das dimensões, incluindo seus valores. Este trabalho introduz uma arquitetura de mediação para auxiliar no consumo de cubos de dados, expostos como triplas RDF e armazenados em bancos de dados relacionais. Os cubos de dados são descritos em um catálogo usando vocabulários padronizados e são acessados por métodos HTTP usando os princípios de REST. Portanto, este trabalho busca tirar proveito tanto dos princípios de dados interligados quanto dos princípios de REST para descrever e consumir os cubos de dados interligados de forma simples e eficiente.

\section{Palavras-chave}

Dados estatísticos, dados ligados, arquitetura de mediação, triplificação, RDF, Cubo de Dados OLAP, REST. 


\section{Table of Contents}

1 Introduction 12

1.1 Motivation _ 12

1.2 Goal and Contributions _ 13

1.3 Dissertation Structure _ 14

2 Background _ 15

2.1 The World Wide Web architecture__ 15

2.2 The HTTP Protocol _ 16

2.3 The Linked Data concept__ 19

2.3.1. The Linked Data Principles___ 19

2.3.2. The Linking Open Data Project__ 20

2.4 RDF_ 21

2.5 SPARQL Query Language __ 23

2.6 Data Cubes__ 24

2.6.1. OLAP Data Cube __ 24

2.6.2. RDF Data Cube Vocabulary___ 25

2.7 RDF to RDB approaches__ 28

2.7.1. Direct Mapping__ 29

2.7.2. R2RML Vocabulary _ 29

2.8 The Web Service Architecture __ 31

2.8.1. XML/SOAP/WSDL _ 32

2.8.2. REST_ 34

2.8.2.1. REST architecture___ 34

2.8.2.2. RESTful Web services __ 36

2.9 Summary_ 36

3 Related Work__ 38

3.1 OLAP data approaches __ 38

3.2 RESTful Linked Data approaches__ 40 
3.3 Summary 42

4 The OLAP2DataCube Catalog On Demand Framework 43

4.1 Overview of the OLAP2DataCube Catalog On Demand 43

4.2 Data cube consumption 46

4.2.1. Stage 1: Selection of a Data Cube 46

4.2.2. Stage 2: Requesting Data Cube Metadata 46

4.2.3. Stage 3: Triplification of a Data Cube 46

4.3 Summary 47

5 The LDC Mediator 48

5.1 Combining REST and Linked Data 48

5.2 The LDC Mediator components 49

5.3 Implementation of the LDC Mediator 50

5.3.1. The Mediator Engine package 51

5.3.2. The Metadata Service package 53

5.3.3. The RDB-to-RDF package 54

5.4 Consuming data cubes with the LDC Mediator 55

5.4.1. Datasets collected 55

5.4.2. The RESTful Web service definition 57

5.4.3. Requesting a cube metadata 57

5.4.4. Requesting cube observations 60

5.5 Summary 62

6 Conclusion 64

6.1 Contributions 64

6.2 Limitations and Future work 64

7 Bibliography 66 


\section{List of Figures}

Figure 1: The three architectural bases of the Web__ 16

Figure 2: A HTTP request method example

Figure 3: The LOD Cloud Diagram at September 2011___ 21

Figure 4: An RDF graph example __ 22

Figure 5: A simple SPARQL query __ 23

Figure 6: The RDF Data Cube Vocabulary key terms ___ 26

Figure 7: A Data cube example__ 26

Figure 8: Dimension properties __ 27

Figure 9: A measure property ___ 27

Figure 10: A data cube description (the dataset definition part) __ 28

Figure 11: A data cube description (the data structure part) __ 28

Figure 12: Direct Mapping example___ 29

Figure 13: Overview of the R2RML Vocabulary _ 30

Figure 14: An R2RML mapping example___ 31

Figure 15: Web Services Architecture Stack __ 32

Figure 16: A SOAP request and response example __ 33

Figure 17: A WSDL structure___ 34

Figure 18: REST Data Elements ___ 35

Figure 19: The QB4OLAP Vocabulary__ 39

Figure 20: Overview of the OLAP2DataCube Catalog On Demand __ 44

Figure 21: LDC Mediator components__ 49

Figure 22: Mediator Engine package___ 51

Figure 23: The Jersey implementation of the Data Cube resource __ 52

Figure 24: Metadata Service package ___ 53

Figure 25: The generic method to execute a SPARQL__ 53

Figure 26: RDB-to-RDF Converter package __ 54

Figure 27: A residents star schema__ 56

Figure 28: List of cubes _ 57

Figure 29: Return of the cube metadata request __ 58 
Figure 30: SPARQL Query to return a metadata cube subset 59

Figure 31: Searching dynamically triples related to a resource 59

Figure 32: R2RML mapping file to the residents cube 61

Figure 33: An observation generated 62 


\section{List of Tables}

Table 1: The main HTTP methods __ 17

Table 2: Some of the HTTP status codes _ 18

Table 3: Comparing the related OLAP approaches___ 40

Table 4: The JAX-RS most important annotations __ 52

Table 5: DB2Triples parameters __ 54

Table 6: LDC RESTful API methods __ 57 